\title{
等方性高密度黒鉛の酸化消耗
}

\section{Weight loss of isotropic high-density graphite during oxidation}



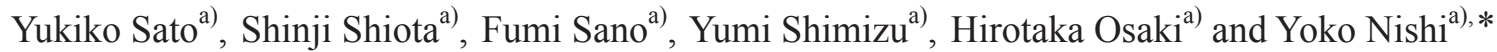

\begin{abstract}
The weight loss of isotropic high-density graphite products as a result of oxidation was measured at different temperatures under a constant flow of dried air: at $550^{\circ} \mathrm{C}$ for $24 \mathrm{~h}$ under an air flow of $4 \mathrm{~L} \mathrm{~min}^{-1}$, at $700{ }^{\circ} \mathrm{C}$ for $2.5 \mathrm{~h}$ under $4 \mathrm{~L} \mathrm{~min}^{-1}$, and at $1200^{\circ} \mathrm{C}$ for $1 \mathrm{~h}$ under $2 \mathrm{~L} \mathrm{~min}{ }^{-1}$. By observing the changes in the surface and cross-section of the specimen with oxidation, the weight loss is discussed in relation to the bulk density and whether a purification process was included during the graphite production. At $550{ }^{\circ} \mathrm{C}$, oxidation even occurred inside the block and was markedly accelerated by the presence of metallic impurities, leaving small etch pits with a round cross-section. Weight loss on graphite products without a purification process was $10 \sim 100$ times larger than that on products after purification. The weight loss at $1200^{\circ} \mathrm{C}$ could be related to the bulk density for all graphite samples, with or without purification.
\end{abstract}

KEYWORDS : Isotropic high-density graphite, Oxidation, Bulk density, Catalytic oxidation

\section{1. 緒 言}

等方性高密度黒鉛は原子炬構造材として用いられるのみでな く, 半導体製造用のヒータ, サセプタなど多くの先端産業に使 われている。それらの用途は，黒鉛材料一般の耐熱性，電気お よび熱に対する高伝導性，軽量性などの特徴に加えて，高い密 度を持たせ，材料の方向による性質の違いをなくすことによっ て拓かれたものである。当社では，1973年から等方性高密度 黒鉛の生産を開始し，大型ブロックの生産に成功するなど多く の実績を有している1)。

一方，黒鉛を含めた炭素材料すべてに扔いて，酸化されやす く消耗することが，特に高温での使用に際して問題となる。炭 素材料の酸化については多くの研究がなされており, 炭素材料 の構造，組織はもちろん，酸化温度㧍よび酸化郕に強く依存

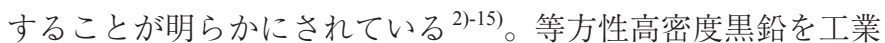
材料として提供するにあたり，その構造や組織を表すX線パラ メー夕, 真密度, かさ密度, 強度, 弾性率などの物性值に加え て，酸化消耗の基本的なデー夕を提供，公開することを求めら れる場合が多い。当社では，酸化消耗についての社内規格を作 成し，そのデータをユーザーに提供している。
本報では，等方性高密度黒鉛の酸化消耗率を当社規格に従っ て決定するとともに，酸化処理後の試験片の表面状態を走査電 子顕微鏡で観察し，試験片断面を光学顕微鏡で観察した。そし て，測定された酸化消耗率をかさ密度抢よび高純度化処理の有 無と関係づけて検討した。この検討を通して，当社の酸化消耗 率測定試験規格の妥当性を検討した。

\section{2. 実 験}

\section{1 試料}

当社製等方性高密度黒鉛のうち，かさ密度や灰分量の異な る 14 種類の製品を選択し， $20 \times 32 \times 12.5 \mathrm{~mm}$ の大きさの試験 片を切り出した。試験片は，アセトン溶液中で超音波洗浄後, $100{ }^{\circ} \mathrm{C}$ で 2 時間乾燥させた。酸化消耗測定前の重量と寸法を計 測し，かさ密度を算出した。

使用した等方性高密度黒鉛の真密度，かさ密度，灰分含有 量の範囲をTable 1 に示した。真密度および扊分含有量は，JIS R 7222 ${ }^{16)}$ jよよびR 7223 $3^{17)}$ に従って決定した。ここで用いた黒 鉛は，14種の製品銘柄から選んだ 110 の試験片からなり，それ らのかさ密度はいずれも $1.75 \sim 1.95 \mathrm{~g} \mathrm{~cm}^{-3}$ の範囲にあるが, 灰 分含有量は高純度化処理の有無により，Table 1 に示したよう

Table 1 Density and ash content in isotropic high-density graphite samples used.

\begin{tabular}{|c|c|c|c|c|c|c|}
\hline Sample group & $\begin{array}{c}\text { Purification } \\
\text { treatment }\end{array}$ & $\begin{array}{l}\text { Number of product } \\
\text { grades }\end{array}$ & $\begin{array}{c}\text { Total number of } \\
\text { oxidized specimens }\end{array}$ & $\begin{array}{l}\text { True density } \\
\left(\mathrm{g} \mathrm{mL}^{-1}\right)\end{array}$ & $\begin{array}{l}\text { Bulk density } \\
\quad\left(\mathrm{g} \mathrm{mL}^{-1}\right)\end{array}$ & $\begin{array}{l}\text { Ash content } \\
(\operatorname{mass} \%)\end{array}$ \\
\hline $\mathrm{N}$ & No & 10 & 90 & $2.13 \sim 2.21$ & $1.75 \sim 1.95$ & $0.01 \sim 0.09$ \\
\hline $\mathrm{P}$ & Yes & 4 & 20 & $2.18 \sim 2.21$ & $1.75 \sim 1.90$ & $\leqq 0.002$ \\
\hline
\end{tabular}


に大きく二つのグループに分けられた。高純度化処理を行った 試料（以下，グループPとする）の灰分含有量は 0.002 mass $\%$ 以下と非常に少ない。これに対して，高純度化処理を行って いない試料（以下，グループ $\mathrm{N}$ とる）の灰分含有量は $0.01 〜$ $0.09 \mathrm{mass} \%$ の範囲である。灰分は試料中に含有する金属を酸化 物として定量しており，含有金属種および含有量を意図的に制 御しているわけではない。したがって，製品銘柄および製造時 期によって，灰分量は 0.08 mass\%の狭い範囲ではあるがばら ついている。また，灰分中の金属種をエネルギー分散X線分光 装置(EDX)によって同定した結果， $\mathrm{Ti}, \mathrm{V}, \mathrm{Fe}, \mathrm{Ni}$ などが検出され たが，その相対割合は試験片ごとにばらついており，一定の傾 向は認められなかった。なお，ここで用いた等方性高密度黒鉛 の灰分含有量は，人造黒鉛電極（約 0.2 mass \% 以上）に比べて 1 桁以上低い。

\section{2 酸化処理}

酸化処理には，Fig. 1に示した管状電気炉を用いた。試験片 2 個を，Fig. 1中に拡大して示したように，ガス流に平行となるよ うホルダーから約 $4 \mathrm{~mm}$ 浮かせ，互いに約 $18 \mathrm{~mm}$ 離して置いた。 窒素ガス流通下で $550{ }^{\circ} \mathrm{C}$ と $700{ }^{\circ} \mathrm{C}$ は約 80 分， $1200{ }^{\circ} \mathrm{C}$ は約 4 時 間かけて目的温度まで昇温した。エアドライヤーを通すことで 水蒸気を取り除き，露点を $-60{ }^{\circ} \mathrm{C}$ まで下げた乾燥空気を，目的 温度まで昇温させた炉の中へ一定流速で流した。酸化処理は,

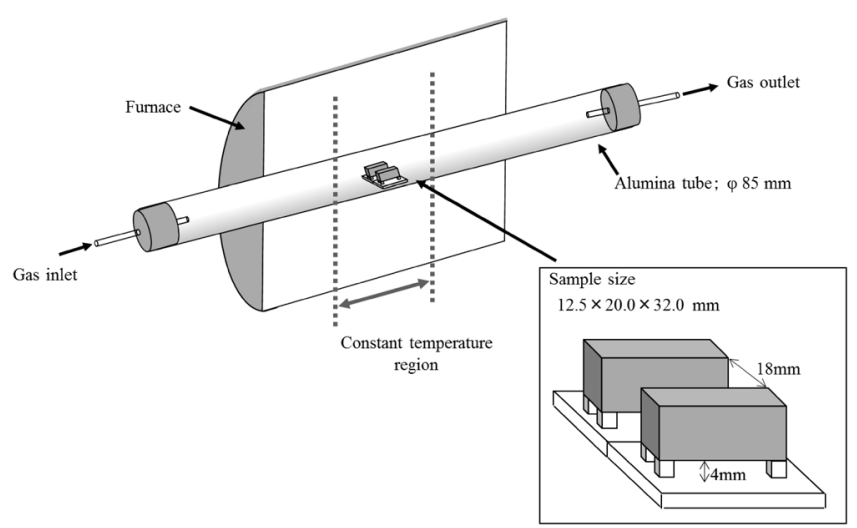

Fig. 1 Oxidation furnace used and the arrangement of two specimens in the furnace.
(1)空気流速 $4 \mathrm{~L} \mathrm{~min}^{-1}$ 下に $550{ }^{\circ} \mathrm{C}$ で 24 時間保持，(2)空気流速 $4 \mathrm{~L} \mathrm{~min}^{-1}$ 下に $700{ }^{\circ} \mathrm{C}$ で 2.5 時間保持，(3)空気流速 $2 \mathrm{~L} \mathrm{~min}^{-1}$ 下に $1200{ }^{\circ} \mathrm{C}$ で 1 時間保持の 3 条件で実施した。試験片は各条件で酸 化させた後，窒素ガスに変更し，炉内で放冷した。

酸化処理前後の重量変化から酸化消耗率を算出した。さらに 酸化処理前後の試験片表面について走査電子顕微鏡（SEM日立 製作所）で観察を行うとともに，金属不純物の同定をSEMに付 属させたEDX（堀場製作所）によって行った。また，酸化処理 した試験片内部を観察するため，Fig. 2 に示したように，試験片 をのこぎりで切断してその断面を樹脂埋め研磨した後，光学顕 微鏡（OPMオリンパス）で観察した。さらに，試験片中に含ま れる金属種を特定するため, 酸化消耗測定後試験片を粉砕し, 蛍光X線装置（XRFリガク）にて金属種の同定を行った。

\section{3. 結 果}

\section{1 各温度での酸化消耗率}

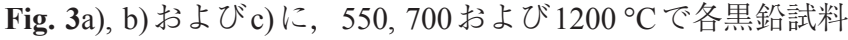
について測定した酸化消耗率を，かさ密度に対してプロットし た。各温度での酸化消耗率は，特徴的な挙動を示した。

$550{ }^{\circ} \mathrm{C}$ での酸化消耗率(Fig. 3a)) は，高純度化処理をした黒鉛 （グループP）では 0.1 0.5 mass\% と非常に低いのに対して，高 純度化していない黒鉛（グループN）ではグループPよりも高 い值を示した。グループ Nでは 10 種の製品銘柄間の酸化消耗 率が 1 ～ 22 mass \% とばらつきが大きく，ここでは，酸化消耗率 でさらに二つのグループに分けて検討することにした。 $550{ }^{\circ} \mathrm{C}$ での酸化消耗率が平均で 5 mass $\%$ 以上の銘柄を $\mathrm{N}-1,5 \mathrm{mass} \%$ 以

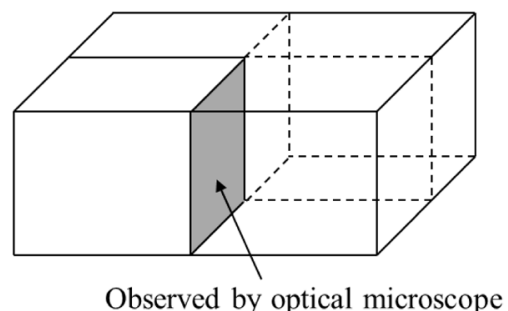

Fig. 2 Cutting of the specimen after oxidation in order to observe its inside. a) at $550^{\circ} \mathrm{C}$ for $24 \mathrm{~h}$

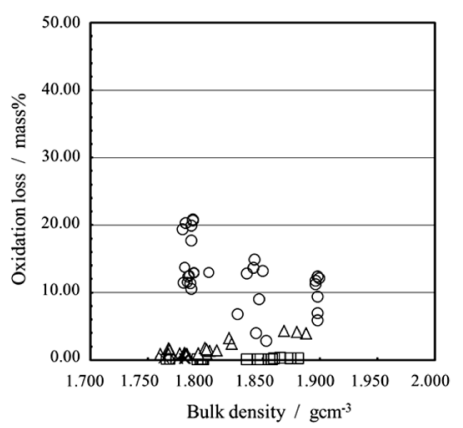

b) at $700{ }^{\circ} \mathrm{C}$ for $2.5 \mathrm{~h}$

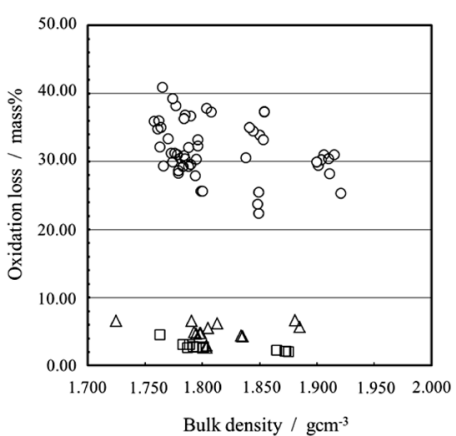

c) at $1200^{\circ} \mathrm{C}$ for $1 \mathrm{~h}$

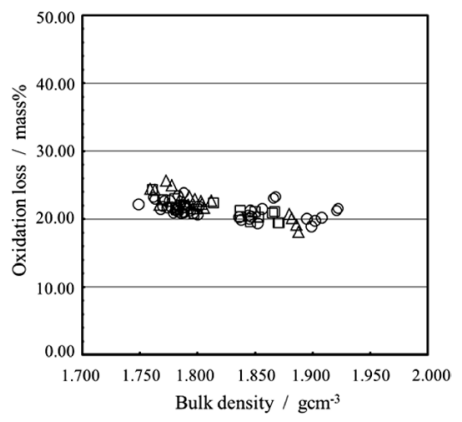

Fig. 3 Dependences of oxidation loss on bulk density for high-density isotropic graphite samples. Non-purified samples were divided two groups by oxidation loss at $550{ }^{\circ} \mathrm{C} . \circ$ : group $\mathrm{N}(\mathrm{N}-1), \triangle$ : group $\mathrm{N}(\mathrm{N}-2), \square$ : group P. a) Oxidation at $550{ }^{\circ} \mathrm{C}$, b) $700{ }^{\circ} \mathrm{C}$ and c) $1200{ }^{\circ} \mathrm{C}$. 
下の銘柄を N-2 とした。

グループ Nの酸化消耗率のばらつきは, 金属不純物の含有量 のばらつきに起因していると考えられた。そこで，酸化消耗率 を灰分含有量に対してプロットしたところ，灰分が多いほど酸 化消耗率が大きくなる傾向は見受けられた。しかしながら，有 意な相関性を認めることはできなかった。このことは，不純物 金属をまとめて灰分として定量しており，金属種を考慮してい ないためと考えられる。

そこで，試験片中に含まれる金属種を特定するため，酸化消 耗測定後試験片の蛍光X線測定を実施し，金属種を調べた。グ ループNのうち酸化消耗率が大きい試験片 (N-1) と小さい試験 片 $(\mathrm{N}-2)$ から任意の各 1 個, グループ Pから任意の1個を選択し て測定した結果，N-1 試験片からは $\mathrm{Si}, \mathrm{Ca}, \mathrm{Ti}, \mathrm{Fe}, \mathrm{N}-2$ 試験片か らは Si, Vが検出された。グループPの試験片からの検出元素 はなかった。グループN-1およびN-2の測定結果のように，製 品銘柄によって含まれる金属種が異なっており，また，同一銘 柄でもロットが異なると今回検出されたものとは異なる金属種 を含んでいる可能性があるため, どの金属種が酸化消耗に寄与 しているかを明らかにすることはできなかった。

$700{ }^{\circ} \mathrm{C}$ での酸化消耗率は，グループ $\mathrm{N}$ のばらつきが $550{ }^{\circ} \mathrm{C} の$ 場合よりさらに大きかった。グループN-1 試料は $22 \sim 41 \mathrm{mass} \%$ と大きい消耗率を示す一方，グループ N-2の試料は酸化消耗 率が小さく，グループ P試料の消耗率に近い值を示した $($ Fig. 3b))。

$550{ }^{\circ} \mathrm{C}$ おび $700{ }^{\circ} \mathrm{C}$ での酸化消耗率とかさ密度の関係を見る と，特にグループN-1でかさ密度が低いものほど酸化消耗率が 大きくなる傾向が見られた。

$1200{ }^{\circ} \mathrm{C}$ での酸化消耗率(Fig. 3c)) は, 高純度化処理の有無に よる差は認められず，ほぼ一定值であった。高純度化処理の有 無や，試料中に含まれる金属種および金属含有量にはほとんど 関係なく酸化が進行していると言える。他温度域の測定結果と 同様に, 酸化消耗率はかさ密度に依存する傾向が若干だが見ら
れており，かさ密度が低いものほど酸化消耗率は大きい傾向に あった。

\section{2 酸化処理後の表面および切断面の観察}

酸化温度の違いは, 酸化処理後の試験片の外観にも現れてい た。Fig. 4 に，グループNに属する試料について，酸化処理前 の試験片と各温度で酸化処理した後の試験片の外観写真を示し た。

$550{ }^{\circ} \mathrm{C}$ で 24 時間酸化処理した試験片は，表面が酸化消耗に より若干粗になったように見受けられるが，試験片の外観およ び大きさは，酸化処理前のものと比べると肉眼では区別がつ かなかった。しかし， $1200{ }^{\circ} \mathrm{C} て ゙ 1$ 時間酸化処理した試験片は, 試験片の縁が丸くなっており，寸法も明らかに小さくなって いた。そこで，グループ $\mathrm{N}$ 試料のうち酸化消耗率が大きい試料 $(\mathrm{N}-1)$ と小さい試料 $(\mathrm{N}-2)$ より各 1 種ずつ, グループ P 試料から 1 種を選んで試験片表面の SEM 像および切断面のOPM像の観察 を行った。なお， 3 種の試料はかさ密度が $1.77 \sim 1.80 \mathrm{~g} \mathrm{~cm}^{-3}$ 付 近のものを選んだ。

\section{a) $550{ }^{\circ} \mathrm{C}$ における酸化}

Fig. 5 に，550 ${ }^{\circ} \mathrm{C}$ で酸化消耗させた試験片表面のSEM像を示 した。グループNに属する試料のうち酸化消耗率が大きい試料 (N-1)は，Fig. 5(a-1) および (a-2)に示したように $550{ }^{\circ} \mathrm{C}$ 酸化に
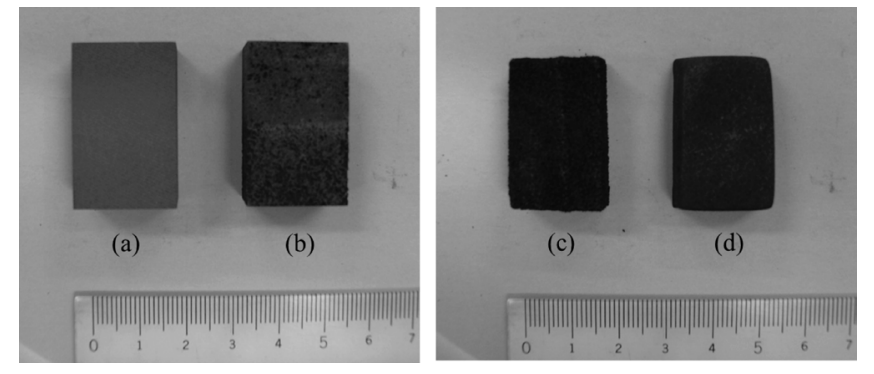

Fig. 4 Appearance of the specimens before and after oxidation. (a) Before oxidation, (b) after oxidation at $550{ }^{\circ} \mathrm{C}$, (c) at $700{ }^{\circ} \mathrm{C}$ and (d) at $1200{ }^{\circ} \mathrm{C}$.
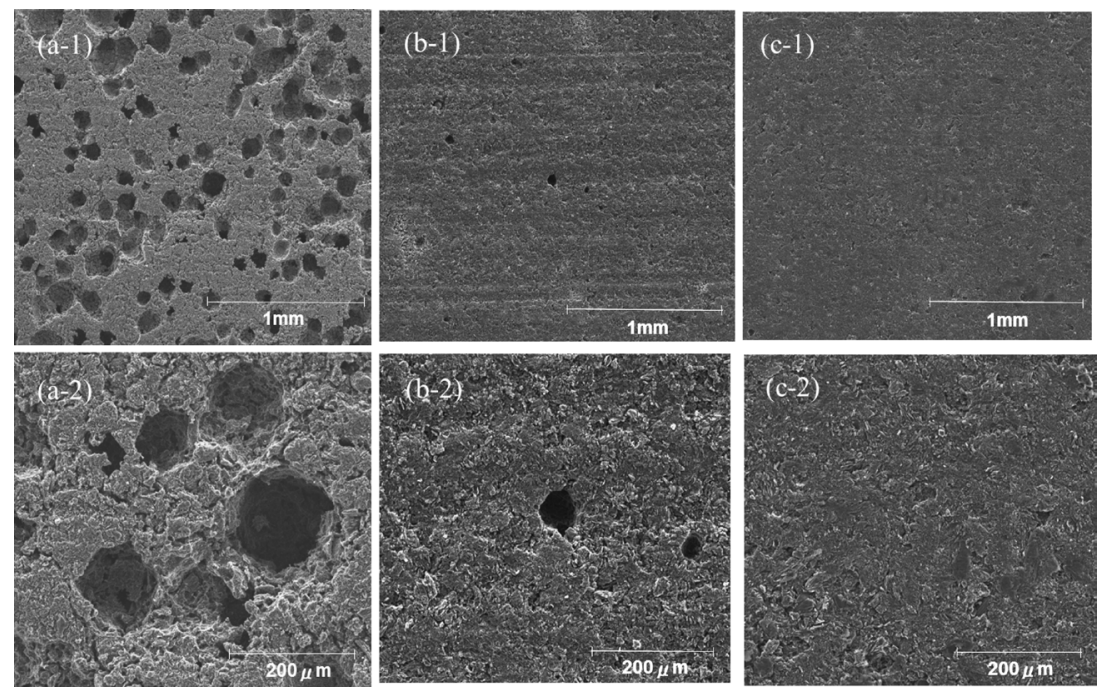

Fig. 5 SEM images of the specimens after oxidation at $550^{\circ} \mathrm{C}$ for $24 \mathrm{~h}$. (a-1) and (a-2) The sample in group $\mathrm{N}$ (N-1) with high oxidation loss, (b-1) and (b-2) that (N-2) with relatively small oxidation loss, (c-1) and (c-2) the sample in group P. 
よって断面がほぼ円形に近い多数の穴が生じていた。これは, 金属を触媒とした酸化によるエッチピット ${ }^{6}$ と考えられる。こ れに対してグループP試料では，Fig. 5(c-1)および(c-2)に示し たように，このようなエッチピットはほとんど認められず，表 面が僅かに荒らされた状態が観察された。グループNに属し酸 化消耗率のより小さい試料(N-2)では，N-1 試料に比べてエッ チピットの数が少なく, ピット深さはN-1のものよりも浅かっ た（Fig. 5(b-1) および(b-2)）。N-1 試料のエッチピットの底部分 をEDXで測定したところ，Ti，Vなどが微粒子として認められ る場合があった。

エッチピット以外の場所では，酸化によって表面が荒らされ た様子が認められ，原料としたコークス粒同士の境界部分が 選択的に酸化されて生じた不定形のピットが観察された。しか し，黒鉛による差を認めることは難しかった（Fig. 5(a-2), (b-2) および(c-2))。

$550{ }^{\circ} \mathrm{C}$ 酸化処理後の試験片切断面のOPM像をFig. 6 に示し た。各OPM像において, 右辺の中央が試験片の中心であり, 他 の3つの辺が試験片の外表面である。N-1 試料では多数の円い エッチピットが認められた(Fig. 6(a))。エッチピットはブロック 表面に多く生成しており，ブロック中央に向けて減少する傾向 にあるが，中心部でもエッチピットの生成は明らかに認められ た。 N-2 試料でもエッチピットが認められたが，N-1試料よりも その数ははるかに少なく, 試験片全体に点在していた。また, エッチピットの径はN-1 試料のものより小さかった(Fig. 6(b))。P 試料では円形のエッチピットはほとんど見られず，コークス粒 境界付近に不定形のピットが認められた $($ Fig. 6(c))。

\section{b) $700{ }^{\circ} \mathrm{C}$ における酸化}

Fig. 7 およびFig. 8 に，700 ㄷ で酸化消耗させた試験片表面の SEMおよび切断面の OPM像を示した。N-1 試料では, 試験片 表面が激しく消耗して多数の穴が生成しており，それらが互い につながった部分も多数観察された（Fig. 7(a-1)および(a-2)）。 このような激しい酸化消耗は, Fig. 8(a)の切断面のOPM像か
ら分かるように，試験片表面付近（表面から深さ $1 \mathrm{~mm}$ 以下の 範囲）に限られており，試験片内部にはほとんどエッチピット は認められなかった。これらの表面付近のエッチピットはいず れも円形に近い断面を持っていた。一方，N-2 試料の試験片で は, 円いエッチピットの数ははるかに少数で, 径も小さかった。 また，ピットがつながっている状態は認められなかった（Fig. 7(b-1)および7(b-2))。P試料では N-1 およびN-2 試料のような円 いエッチピットではなく, 不定形のピットが多数観察された

(Fig. 7(c-1), (c-2) およびFig. 8(c))。

\section{c) $1200{ }^{\circ} \mathrm{C}$ における酸化}

$1200{ }^{\circ} \mathrm{C}$ 酸化処理後の N-1 試料の像を Fig. 9 に示す。 $1200{ }^{\circ} \mathrm{C}$ については，各グループ試料の表面のSEM像および切断面の OPM像に大きな差は認められなかったので，N-1 試料の像のみ を示した。

Fig. 4(d)の外観写真と同様に，試験片の縁が酸化されて丸く なっていた(Fig. 9(b))。さらに, 試験片表面が荒らされ, 原料 コークスの粒子が認められた(Fig. 9(a-2))。このことから，コー
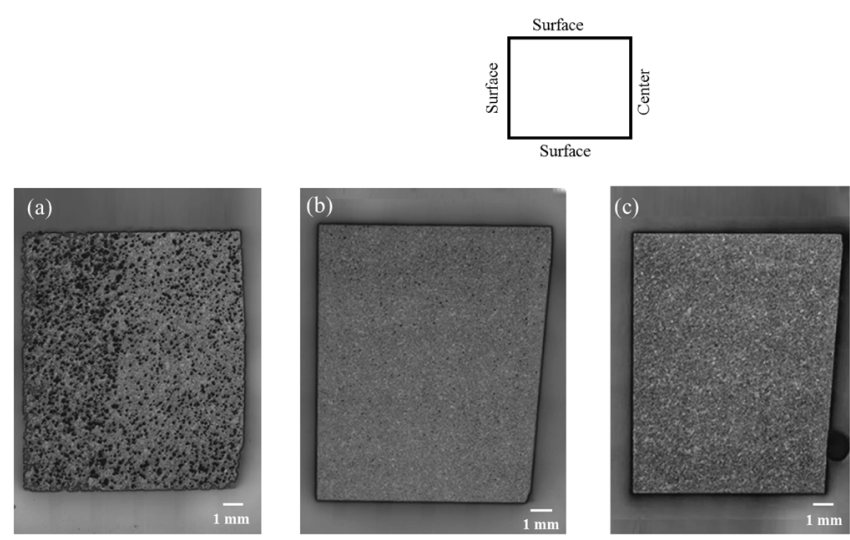

Fig. 6 Optical micrographs of the cross-section of the specimens after oxidation at $550{ }^{\circ} \mathrm{C}$ for $24 \mathrm{~h}$. (a) The sample in group $\mathrm{N}$ $(\mathrm{N}-1)$ with high oxidation loss, (b) that $(\mathrm{N}-2)$ with relatively small oxidation loss, (c) the sample in group P.
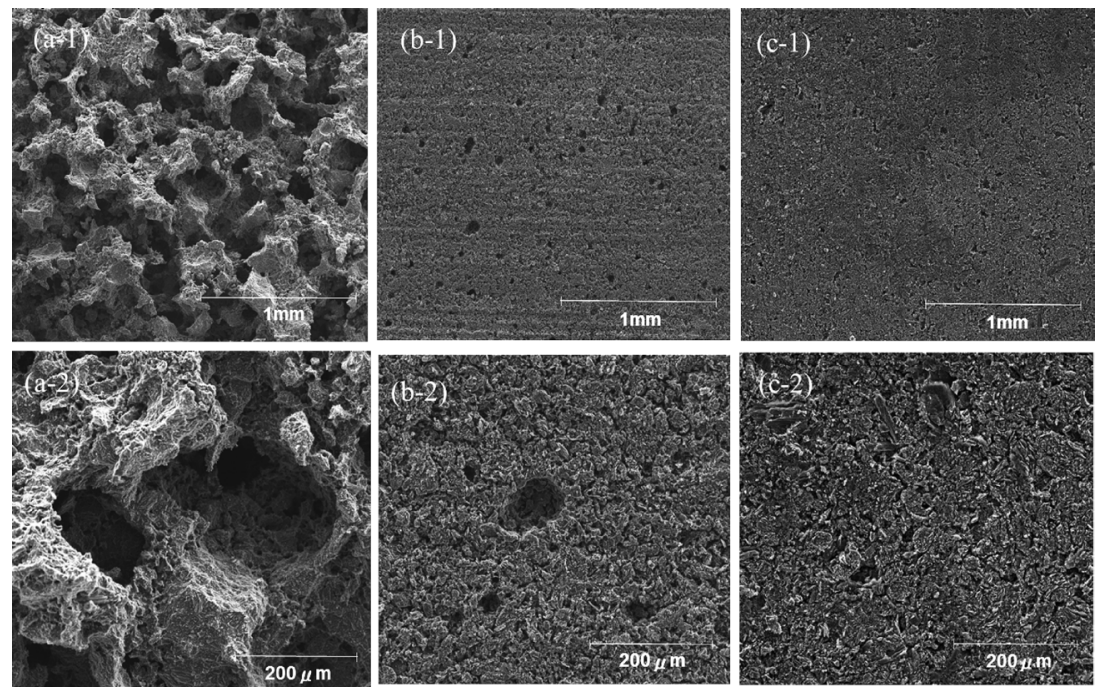

Fig. 7 SEM images of the specimens after oxidation at $700^{\circ} \mathrm{C}$ for $2.5 \mathrm{~h} .(\mathrm{a}-1)$ and (a-2) The sample in group $\mathrm{N}(\mathrm{N}-1)$ with high oxidation loss, (b-1) and (b-2) that (N-2) with relatively small oxidation loss, (c-1) and (c-2) the sample in group P. 

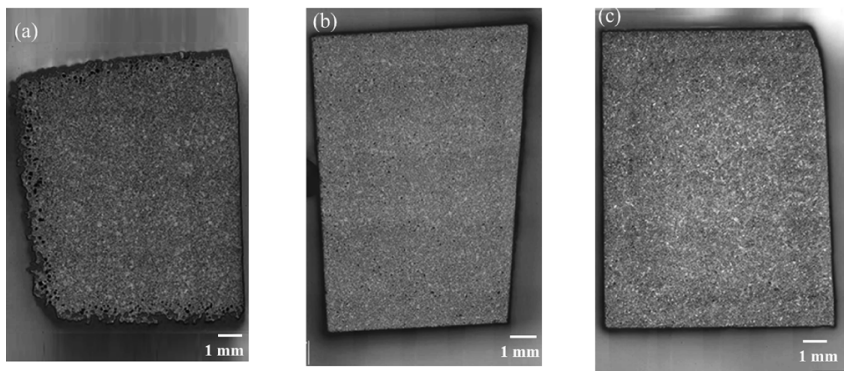

Fig. 8 Optical micrographs of the cross-section of the specimens after oxidation at $700{ }^{\circ} \mathrm{C}$ for $2.5 \mathrm{~h}$. (a) The sample in group $\mathrm{N}(\mathrm{N}-1)$ with high oxidation loss, (b) that $(\mathrm{N}-2)$ with relatively small oxidation loss, (c) the sample in group P.

クス粒子間のバインダーピッチ由来の炭素が選択的に酸化され

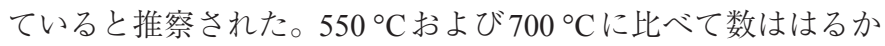
に少ないが，円いエッチピットも観察された。

\section{4. 考 察}

炭素材料のガスによる酸化は，その反応速度が律速過程とな る段階と, 酸化ガスの拡散速度が律速過程となる段階が存在す ることはよく知られている2),3)。等方性高密度黒鉛ブロックを 試験片とした本研究の結果は，この二つの段階が存在するこ

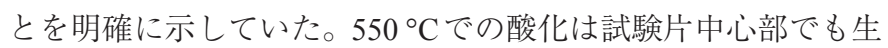
じていたことから, 炭素と酸化ガス (酸素) との接触は十分で あり, 酸化消耗は酸化反応速度によって律速されていると言

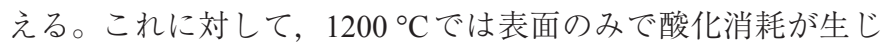
ていた。これは, 酸化反応速度が非常に速く, 試験片内部にま で酸素が拡散することができなかったためと考えられる。した がって, $1200{ }^{\circ} \mathrm{C}$ の酸化消耗は, 酸素の黒鉛試験片表面への拡 散速度によって律速されていると言える。700 ${ }^{\circ} \mathrm{C}$ は酸化反応速 度と酸素ガスの拡散速度が拮抗し, 反応律速段階と拡散律速段 階の中間にあると考えられる。

空気流速 $4 \mathrm{~L} \mathrm{~min}^{-1}$ 下， $550{ }^{\circ} \mathrm{C} て ゙ 24$ 時間酸化処理したグルー プPの黒鉛の酸化消耗率は $0.1 \sim 0.5 \mathrm{mass} \%$ と非常に低かった。 これらの黒鉛は金属不純物の含有量が非常に少なく, 測定さ れた酸化消耗量は黒鉛と酸素の化学反応による質量減少に非 常に近い值と考えられる。これに対して, 高純度化処理を施し ていないグループNの黒鉛を同条件下で酸化処理すると, 高純 度処理品と比べて約 10 100倍の消耗量を示し, その絶対值は 1 22 mass\%の広い範囲にわたっていた(Fig. 3a))。このこと は，黒鉛中の不純物金属の触媒作用により酸化反応が加速され るために，酸化消耗量は金属の含有によって大きくなったと考 えられる。しかも, 酸化反応が加速されるのは金属粒子の周囲 に限られるために, 円形に近い断面を持つエッチピットが多数 検出されたと考えられる(Fig. 6(a))。しかしながら，前述した ように，灰分量と酸化消耗率との間には有意な相関性を見いだ すことができなかった。Table 1 に示したように，グループN 試料の灰分量は $0.01 \sim 0.09$ mass\%の狭い範囲にある。したがっ て, グループN-1 と N-2で酸化消耗率が 1 桁近く異なること
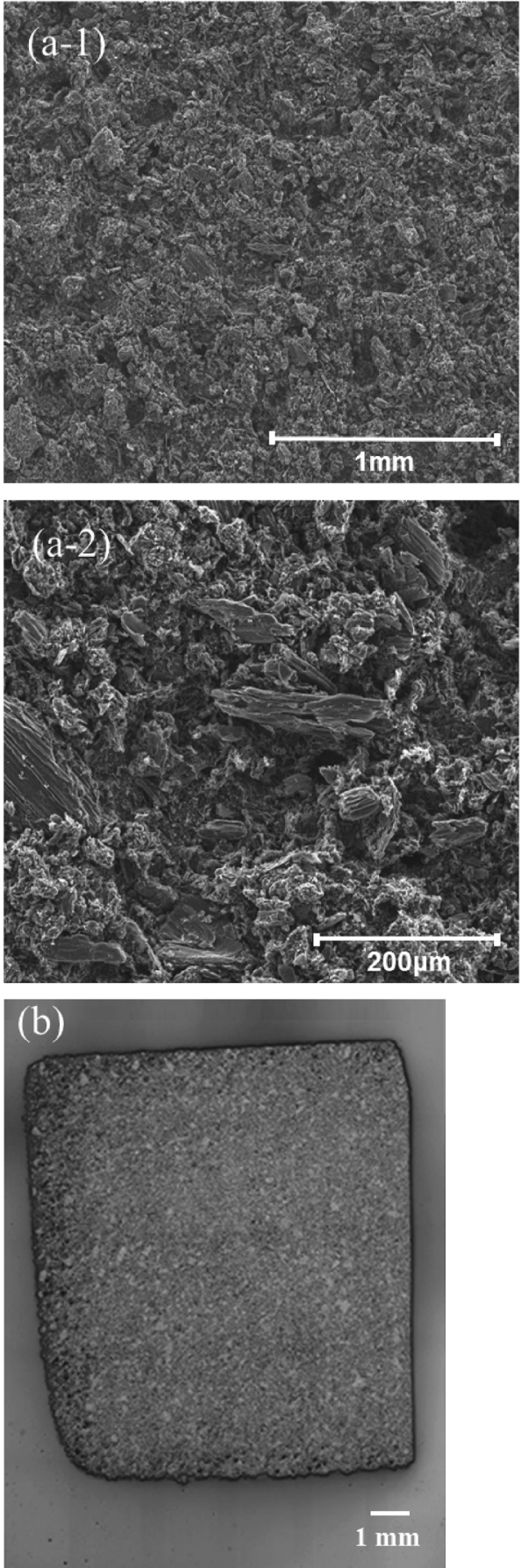

Fig. 9 SEM images (a) and optical micrographs (b) of the specimen $\mathrm{N}-1$ after oxidation at $1200^{\circ} \mathrm{C}$ for $1 \mathrm{~h}$.

(Fig. 3a)) は，灰分に含まれる金属が異なっていることを示唆し ているが，本研究では明らかにすることができなかった。種々 の金属がそれぞれ固有の酸化促進効果（ガス化反応に対する触 媒活性として示されている(4),6) $)$ を持つことが指摘されている。 しかし，本研究で用いた黒鉛試料はいずれも工業製品であり， トータルの金属含有量は低く抑えるように注意が払われている が，含有する金属種までも制御されているわけではないので， 製品銘柄によって酸化消耗率にばらつきが生じており，個々の 金属の酸化消耗への寄与を特定することはできなかった。

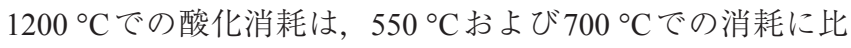


べて格段に速いため，空気流速を $2 \mathrm{~L} \mathrm{~min}^{-1}$ と低くするととも に，保持時間を 1 時間に短縮せざるをえなかった。しかし，そ

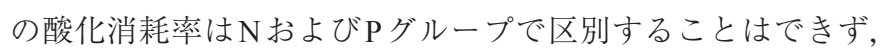

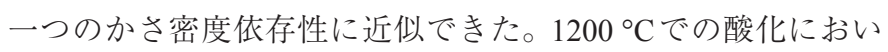
ても，金属が触媒として作用した場合に認められる円形断面の エッチピットが僅かであるが認められた(Fig. 9)。1200 ${ }^{\circ} \mathrm{C}$ の高 温では，金属不純物による酸化反応の加速も生じたが，酸素ガ スと炭素原子の反応（酸化反応）が，より急速に生じたことを 示唆している。

酸化温度 $550{ }^{\circ} \mathrm{C}$, 酸化時間 24 時間という条件を選ぶことに よって，灰分として定量される金属不純物量が 0.01 mass $\%$ と低 い值でも，その存在がエッチピットとして可視化し得ることが 明らかとなった。Fig. 6(a)に示した黒鉛では，金属がほぼ均一 に分散していると言える。この手法を用いれば，黒鉛ブロック 中の金属不純物の存在が可視化でき，その分散状態を明らかに できる。 $1 \mathrm{mass} \%$ 以上の灰分を含んでいる製鋼用黒鉛電極につ いては，鉄などの金属のX線透過率が低いことを利用してその 分布を測定する方法(radiograph)および，七ラミック平板上に 静置した黒鉛を酸化，ガス化することによって灰分の分布とし て金属不純物の分布を測定する方法(ash pattern)が提案されて いる ${ }^{18)}$ 。しかし，0.1 mass\%以下の低い灰分含有量を持ち，金 属不純物が微粒子として存在している高密度等方性黒鉛にこれ らの方法を用いることは極めて難しい。

酸化消耗率は，その測定条件からも強い影響を受ける。たと えば，酸化のための炉の形状および大きさ，試験片の大きさお よび設置状態，酸化剂としての空気の流速および湿度，酸化さ せる温度と保持時間などが挙げられる。本報では，これらの条

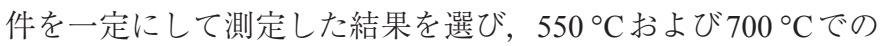
グループ $\mathrm{N}$ 試料についてのばらつき(Fig. 3)を，微量ではある が確実に存在している不純物金属種によるものとして議論し た。しかし，本報で使用した酸化消耗率の值は，長期間（約 4 年間）にわたり測定した結果を比較していることから，測定期 間中にこれらの測定条件が僅かに変わっているかもしれないと いう疑いを完全にぬぐい去ることはできない。たとえば，偶発 的な湿度の増加は酸化消耗率を大きく増やすことが予想され る。今後, さらにこれらの測定条件の正確さを上げるととも に，より精確に制御が可能な測定条件を模索していく必要があ るだろう。

\section{5. 結 論}

$550{ }^{\circ} \mathrm{C}$ での酸化は，酸素ガスの試験片内部への拡散が十分 であり，酸化消耗は酸化反応速度によって律速され，しかも， 酸化反応は金属不純物によって加速された。これに対して,
$1200{ }^{\circ} \mathrm{C}$ での酸化は，酸化反応が急速に進むために試験片内部 にまで酸化が及ばず，試料表面で酸化が進行した。また，金属 不純物により酸化反応が加速されることが少なく，高純度化処

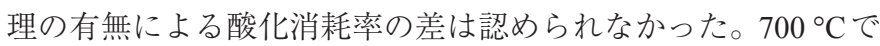
の酸化は，反応律速段階と拡散律速段階のほぼ中間段階であっ た。

本研究の結果から，酸化消耗率を決定するために当社規格 で採用している条件，すなわち，(1)空気流速 $4 \mathrm{~L} \mathrm{~min}^{-1}$ 下に $550{ }^{\circ} \mathrm{C}$ で 24 時間保持，(2)空気流速 $4 \mathrm{~L} \mathrm{~min}^{-1}$ 下に $700{ }^{\circ} \mathrm{C} て ゙ 2.5$ 時 間保持，(3)空気流速 $2 \mathrm{~L} \mathrm{~min}^{-1}$ 下に $1200{ }^{\circ} \mathrm{C} て ゙ 1$ 時間保持はほぼ 妥当な条件であると言える。なお，酸化ガスとして空気を用い ることは簡便ではあるが，その乾燥には十分に注意を払う必要 がある。

$550{ }^{\circ} \mathrm{C}$ で酸化することにより，等方性高密度黒鉛中に微量 （灰分として 0.1 mass\%以下）に含まれている金属不純物微粒 子の分布を，エッチピットの分布として簡単に可視化できるこ とが明らかとなった。

\section{謝 辞}

本研究を進めるにあたり，富田英子氏，大西千尋氏にご協力 いただきましたことをここに深謝いたします。

\section{文 献}

1) 近藤純子, 炭素素原料科学と材料設計 IX (CPC 研究会編) (2007) pp. 112-121.

2) 山内 繁, 佐々 正，炭素材料入門（炭素材料学会編）(1972）pp. 74-81.

3) 今井 久, 改訂炭素材料入門 (炭素材料学会編) (1984) pp. 75-85.

4) 京谷 隆, 新 - 炭素材料入門（炭素材料学会編）(1996) pp. 62-68.

5) I. W. Smith, Fuel 57 (1978) 409-414.

6) E. Breval, M. Klimkiewicz, D. K. Agrawal and F. Rusinko Jr., Carbon 40 (2002) 1017-1027.

7) L. Babout, P. M. Mummery, T. J. Marrow, A. Tzelepi and P. J. Withers, Carbon 43 (2005) 765-774.

8) J. R. Hahn, Carbon 43 (2005) 1506-1511.

9) H. Kawakami, TANSO 1986 [No.124] 26-33 [in Japanese].

10) M. Takahashi, M. Kotaka and H. Sekimoto, J. Nucl. Sci. Technol. 31 (1994) 1275-1286.

11) E. L. Fuller and J. M. Okoh, J. Nucl. Mater. 240 (1997) 241-250.

12) E. S. Kim, K. W. Lee and H. C. No, J. Nucl. Mater. 348 (2006) 174-180.

13) E. S. Kim and H. C. No, J. Nucl. Mater. 349 (2006) 182-194.

14) S. H. Chi and G. C. Kim, J. Nucl. Mater. 381 (2008) 9-14.

15) C. I. Contescu, T. Guldan, P. Wang and T. D. Burchell, Carbon 50 (2012) 3354-3366.

16) JIS R 7222: 1997, 黒鉛素材の物理特性測定方法(1997) 日本工業規格 (in Japanese) (Test methods for physical properties of graphite materials).

17) JIS R 7223: 1997，黒鉛素材の化学分析方法(1997) 日本工業規格 (in Japanese) (Chemical analysis of graphite materials).

18) T. Noda and M. Inagaki, Bull. Chem. Soc. Jpn. 36 (1963) 112-114. 